УДК 377.07:339.138

https://doi.org/10.32835/2223-5752.2018.16.40-44.

\title{
МАРКЕТИНГОВІ КОМУНІКАЦІЇ В УПРАВЛІННІ ЗАКЛАДОМ ПРОФЕСІЙНОЇ (ПРОФЕСІЙНО-ТЕХНІЧНОЇ) ОСВІТИ
}

\section{Ганна Харченко,}

в.о директора Державного професійно-технічного

навчального закладу «Конотопський професійний лічей»

ORCID: 0000-0002-7109-7327

e-mail: kharchenkoanna29@gmail.com

\section{КЛЮЧОВІ СЛОВА:}

професійна (професійнотехнічна) освіта, маркетингові комунікації, реклама, персональний продаж, зв'язки з громадськістю
Реферат

У статті визначено суть маркетингових комунікацій та ключові чинники забезпечення конкурентоспроможності сучасних закладів професійної (професійно-технічної) освіти. Проаналізовано основні підходи до управління маркетинговими комунікаціями. Розглянуто вітчизняні та зарубіжні дослідження щодо деяких аспектів маркетингового управління професійними (професійно-технічними) освітніми закладами, а також широкий спектр маркетингових комунікацій, різні види та канали розповсюдження інформації. Охарактеризовано найбільш використовувані засоби маркетингових комунікацій 3 погляду забезпечення успіху закладу на ринку освітніх послуг. Насамперед, це дієва система маркетингових комунікацій, що характеризується широким застосуванням різноманітних комунікаційних засобів і появою нових інструментів інформаційного впливу. З'ясовано значущість таких елементів маркетингових комунікацій, як: реклама, зв'язки з громадськістю (publicrelations), різні види рекламних звернень, ярмарки та виставки, спеціальні події (eventmarketing), прямий маркетинг (direct- marketing), особисті продажі, інтернет-маркетинг, стиль і традиції закладу освіти, неформальні комунікації тощо. Акцентовано увагу на необхідності створення маркетингових та медіа-служб у закладі професійної (професійно-технічної)освіти.

На основі теоретичного аналізу визначено, що зростання ролі маркетингових комунікацій викликане не лише зовнішніми структурними змінами в ринковій економіці, а й особливостями економічних відносин між суб'єктами ринку. Запорукою успіху закладу освіти сьогодні на ринку є спроможність стратегічно правильно організувати взаємодію багатьох інструментів маркетингових комунікацій з визначенням найдієвішого з них.
Постановка проблеми. Незаперечним є те, що нині в Україні відбуваються економічні та соціальні реформи, формуються нові підходи до процесу управління всіма галузями господарства й соціально-культурної сфери, що потребує наукового аналізу й об'єктивного, адекватного відображення причинно-наслідкових процесів в управлінні сучасним навчальним закладом системи професійної освіти.

Актуальність даної статті полягає в принципових змінах, що відбуваються в системі професійної освіти України. На сьогодні ідея конкурентоспроможностіпоступововисувається на передній край суспільної свідомості в Україні. Ïї розвиток та конкурентоздатність у світовому економічному просторі безпосередньо пов'язані 3 розвитком людського потенціалу, джерелом якого $\epsilon$ система освіти 3 притаманними ій гнучкістю, відповідністю епохальним викликам, світовим тенденціям і національним інтересам.

Сучаснесуспільствопотребує відпрофесійної освіти підготовки молоді, здатної відповідати викликам часу, компетентної та мобільної на сучасному ринку праці, 3 громадянською позицією, налаштованої на саморозвиток i навчання впродовж усього життя. I лише той заклад $є$ гарантом нової якісної професійної освіти й навчання, який здатний прогнозувати результати своєї діяльності та моделювати освітній процес на основі досягнень сучасної педагогічної думки, спрямований на успіх i постійне самовдосконалення.

Розвиток ринкових відносин в економіці сучасної України висуває вимогу більш ефективного управління інституційним розвитком закладу освіти, реальний досвід життедіяльності якого виявляє одну з головних проблем - слабкість наукової бази самого управління. До того ж ринкові відносини стають все більш динамічними, складними i важко передбачуваними. Тому убезпечення на належному рівні всіх умов для існування, функціонування й розвитку закладу професійної (професійно-технічної) освіти стає одним 3 
головних завдань управління ним.

Успішна реалізація цього завдання пов'язана 3 нейтралізацією загроз, які можуть генеруватися зовнішнім i/aбо внутрішнім середовищем професійних (професійно-технічних) закладів освіти, їх життєво важливим функціям.

На сьогодні використання маркетингових комунікацій 3 метою покращення своєї діяльності є актуальним для будь-якого освітнього закладу. Саме ті професійні (професійно-технічні) заклади, які вибудували свою маркетингову комунікаційну стратегію, досягають найбільшого успіху. Важливою функцією маркетингу є вивчення ринку освітніх послуг, в результаті реалізації якого обираються потенційні покупці. Незаперечним є й те, що нині в Україні відбуваються економічні та соціальні реформи, формуються нові підходи до процесу управління всіма галузями господарства i соціально-культурної сфери, що потребує наукового аналізу й об'єктивного, адекватного відображення причинно-наслідкових зв'язків в управлінні сучасним закладом системи професійної освіти.

Істотним аспектом підвищення ролі та значущості маркетингу й маркетингових досліджень в умовах становлення ринку стає формування служб маркетингу. Сучасні керівники вважають, що маркетингова служба для стабільного функціонування навчального закладу $\epsilon$ край необхідною, зокрема, це спеціалісти 3 дослідження ринків та маркетингових комунікацій. Вітчизняні науковці досліджують різні аспекти маркетингового управління закладами освіти, а саме: 3.Рябова - маркетингову стратегію як складову освітнього маркетингу i механізм забезпечення конкурентоспроможності закладу освіти; В.Свистун - організацію діяльності його маркетингової служби; Л.Сергєєва маркетинговий інструментарій управління розвитком; Л.Кубська - маркетингову діяльність закладу професійної освіти 3 використанням PR-технологій; Л.Петренко - інформаційне забезпечення управління маркетингом професійної освіти в регіоні; Н.Проценко - розвиток маркетингової компетентності керівників закладів професійної освіти. Водночас, практично не приділяється увага проблемам управління маркетинговими комунікаціями.

Мета статті - здійснити аналіз основних інструментів маркетингових комунікацій для управління конкурентоспроможністю закладу професійної (професійно-технічної) освіти.

Виклад основного матеріалу. Систему маркетингових комунікацій Є. Ромат (2008) визначає як «комплекс, що об'єднує учасників, канали й засоби комунікацій організації, i спрямований на формування одержувачем комунікацій певних цільових установок, які в результаті сприяють досягненню їі маркетингових цілей».

На сьогодні вітчизняними та закордонними науковцями і практиками розроблено достатньо широкий спектр маркетингових комунікацій, причому, організації обирають для своєї діяльності різні види та канали розповсюдження інформації про себе, свої плани та результати, пропозиції щодо співпраці, вибудовуючи обгрунтовану систему комунікативних зв'язків, так званих «маркетингових комунікацій». До них відносять: рекламу, зв'язки 3 громадськістю (publicrelations), ярмарки та виставки, спеціальні подіï (event-marketing), прямий маркетинг (direct-marketing), особисті продажі, інтернетмаркетинг, стиль та традиції навчального закладу, неформальні комунікації тощо.

Реклама - це найбільш розповсюджений метод маркетингових комунікацій, так зване «безособистісне», неперсоніфіковане звернення освітньої організації як до потенційних споживачів освітніх послуг, так i до всіх інших, хто сприймає інформаційне повідомлення. Традиційна реклама може бути друкованою (рекламна поліграфія), зовнішньою (розміщеною за межами приміщень закладу), у вигляді аудіо- та відеоряду або в поєднанні декількох форм одночасно.

У сфері освітніх послуг виділяють такі види рекламних звернень (за Н.Санакоєвою та В.Кушнір): переконуюча, інформативна, нагадуюча.

Переконуюча використовується для установ, які недавно вийшли на ринок, та переконує потенційних споживачів у серйозності своїх намірів i потенціалу, якості пропонованих послуг тощо. Така реклама на етапі виведення послуги формує прихильність до цього закладу, переконує негайно звернутися за додатковою інформацією або просто скористатися послугою. Інформативна має на меті виведення на ринок нової модифікації освітньої послуги; інформує про зміст програм навчання, його технології, 
методики, зміну ціни тощо; може бути спрямована на виправлення вже сформованих несприятливих уявлень про заклад освіти, його послуги, на усунення різних побоювань споживачів, невиправданих негативних чуток. Нагадуюча реклама використовується вже відомими, визнаними освітніми установами або тими, хто вже здійснив переконуючу та інформативну рекламну кампанії; особливо цей вид реклами доречний у період міжсезоння, нагадуючи абітурієнтам про те, що пропоновані послуги можуть їм знадобитися найближчим часом, і тому важливо заздалегідь встановлювати контакти (Санакоєва, 2014, с.195).

Не менш важливим напрямом маркетингових комунікацій $є$ зв'язки з громадськістю (publicrelations), завдяки яким встановлюється двосторонній діалог між закладом освіти та суспільством в цілому 3 метою популяризації освітніх послуг та створення прихильності у цільової групи споживачів зазначених послуг. До цього методу маркетингових комунікацій пред’являють такі вимоги:

- цілеспрямованість (ця діяльність повинна бути організована таким чином, щоби впливати та досягати взаєморозуміння, отримувати інформацію та здійснювати механізм зворотного зв'язку, тобто відповідної реакції тих, на кого спрямована діяльність зв'язків із громадськістю);

- $\quad$ планомірність (діяльність 3 вирішення проблем та розробки логістичного забезпечення здійснюється протягом певного часу, тому вона має бути систематично організованою i включати збір та аналіз необхідної інформації); актуальність (діяльність засновується на реаліях поточної освітньої політики та суспільного оточення);

- суспільний інтерес (діяльність 3 налагодження зв'язків із громадськістю повинна бути взаємовигідною як для організації, так і для iї суспільного оточення; сприяти взаємному узгодженню інтересів організації та суспільства);

- двостороння комунікація (зв'язки 3 громадськістю потребують зворотної реакції суспільного оточення);

- $\quad$ функція управління (діяльність більш ефективна, коли $\epsilon$ частиною комплексного процесу прийняття рішень, що здійснюється керівництвом освітньої установи; діяльність по зв'язках iз громадськістю включає як консультування, так $\mathrm{i}$ роботу 3 вирішення проблем на вищих рівнях організаційної структури) (Пашкус, 2007, с.62-63).

П. Смітом та ін. (2001) були сформовані принципи маркетингових комунікацій. На думку науковців, маркетингові комунікації мають: розпочинатися зі сприйняття споживачем системної діяльності організації; інтегрувати стратегію в цілому 3 потребами й видами діяльності конкретного споживача; координувати комунікації освітнього закладу в межах набору їх інструментів; забезпечувати встановлення контактів і діалогу зі споживачем.

До факторів, що перешкоджають впровадженню маркетингових комунікацій, належать: обмежені витрати часу менеджерів для реалізації маркетингових комунікацій; недостатня оцінка значущості i переваг від застосування маркетингових комунікацій; опір змінам 3 боку персоналу, особливо функціональних підрозділів організацій, які відповідають лише за певну частину комунікаційного процесу; недостатньо гнучка наявна система планування закладу до впровадження маркетингових комунікацій; неготовність зовнішніх агентств, що спеціалізуються на виконанні певної функції - переорієнтуватися до роботи в умовах маркетингових комунікацій (Кузнєцова, 2015)

Процес стратегічного управління маркетинговими комунікаціями повинен бути узгоджений iз місією підприємства та системою стратегічного планування комплексу маркетингу, а також базуватися на виробленні стратегічних цілей у сфері комунікацій.

При цьому розробка стратегічних цілей $\epsilon$ важливим етапом стратегічного управління маркетинговими комунікаціями. Однак у більшості випадків в освітніх закладах немає стратегічної мети, спостерігається неузгодженість комунікаційних зусиль iз загальною маркетинговою діяльністю (Стеценко, 2011).

Висновки. У ході дослідження ми встановили, що саме інтеграційні процеси різних комунікацій формують і маркетингові комунікації як цілісну систему діяльності суб'єкта господарювання. Зазначені нами напрями маркетингових комунікацій не $\epsilon$ повним переліком усіх комунікаційних каналів, доступних освітнім закладам. Усі зазначені комунікації ретельно плануються фахівцями 3 маркетингу або керівництвом навчального закладу. Водночас, потрібно постійно пам'ятати 
та відслідковувати так звані «неформальні комунікаиії», що є неофіційною трансляцією думок (не завжди об'єктивних) про роботу та якість надання послуг закладом освіти. Тому в умовах конкурентної боротьби на ринку освітніх послуг заплановані маркетингові комунікації повинні сприяти покращенню іміджу закладу освіти, забезпеченню достатнього та найкращого за навчальними досягненнями контингенту студентів, а також успішному функціонуванню та матеріальному благополуччю освітньої установи.

\section{Література}

1. Кузик, О., 2014. Стратегічне управління маркетинговими комунікаціями на сучасних підприємствах. Стратегія економічного розвитку України, 34, с. 130-135.

2. Кузнєцова, I., 2015. Економічна сутність та особливості маркетингових комунікацій. Вісник Львівського національного аграрного університету. Серія "Економіка АПК», 22 (1), c. $142-148$.

3. Пашкус, H, 2007. Маркетинг образовательных услуг. СПб: ООО «Книжный Дом».

4. Ромат, Е., 2008. Реклама: практическая теория. СПб: Питер, Питер.

5. Санакоєва, Н., 2014. Планування i реалізація рекламних кампаній у сфері освітніх послуг. Молодий вчений, 6(09), с. 194-196.

6. Смит, П., 2001. Коммуникации стратегического маркетинга. учеб. Пособие. Москва: ЮНИТИ-ДАНА

7. Стеценко, В., 2011. Удосконалення маркетингових комунікаційних стратегій підприємств споживчої кооперації України. Інноваційна економіка: Всеукраїнський науково-виробничий журнал, 1, с.184-189.

\section{KEY WORDS:}

vocational (vocational and technical) education, marketing communications, advertising, personal sales, public relations.

\section{Abstract}

Marketing communications in vocational schools management

Anna Kharchenko, Director of the State Technical University «Konotopsky Professional Lyceum»

The article defines the essence of marketing communications and the key factors which ensure the competitive advantage of modern vocational schools. The basic approaches to management of marketing communications are analyzed. National and foreign studies on some aspects of marketing management of vocational (vocational and technical) schools, as well as a wide range of marketing communications, various types and distribution channels of information are considered. The article analyzes and describes the most used marketing communications tools in terms of ensuring the success of vocational schools in the market of educational services.

First of all, it is an effective system of marketing communications, which is characterized by the wide use of various communication media and the emergence of new tools of information influence. The importance of such marketing communications elements as advertising, public relations (public relations), various types of advertising appeals, fairs and exhibitions, event-marketing, direct marketing (direct marketing, personal sales, Internet marketing, school style and traditions, informal communication, etc.

The importance of marketing and media services in the vocational (vocational and technical) school is emphasized. On the basis of the theoretical analysis it was determined that the growth of the role of marketing communications is caused not only by external structural changes in the market economy, but also by the peculiarities of economic relations between the subjects of the market.

The key to the success of the vocational school today in the market is the ability to strategically correctly organize the interaction of many marketing communication tools with the definition of the most effective tools. 
References

1. Kuzyk, O.,2014. Stratehichne upravlinnia marketynhovymy komunikatsiiamy na suchasnykh pidpryiemstvakh. Stratehiia ekonomichnoho rozvytku Ukrainy, 34, s. 130-135.

2. Kuznietsova, I.,2015. Ekonomichna sutnist ta osoblyvosti marketynhovykh komunikatsii. Visnyk Lvivskoho natsionalnoho ahrarnoho universytetu. Seriia «Ekonomika APK», 22 (1), s. 142-148.

3.Pashkus, N, 2007. Marketynhobrazovatelnykh usluh. SPb: OOO «Knyzhnyi Dom».

4. Romat, E., 2008. Reklama: praktycheskaia teoryia. SPb: Pyter, Pyter.

5. Sanakoieva, N., 2014. Planuvannia i realizatsiia reklamnykh kampanii u sferi osvitnikh posluh. Molodyi vchenyi, 6(09), s. 194-196.

6. Smyt, P., 2001. Kommunykatsyy stratehycheskoho marketynha. ucheb. Posobye. Moskva: YuNYTY-DANA..

7. Stetsenko, V., 2011. Udoskonalennia marketynhovykh komunikatsiinykh stratehii pidpryiemstv spozhyvchoi kooperatsii Ukrainy. Innovatsiina ekonomika: Vseukrainskyi naukovovyrobnychyi zhurnal, 1, s.184-189.

\section{УДК 378.046-021.64:37.014.6}

https://doi.org/10.32835/2223-5752.2018.16.44-49

\section{УПРАВЛІННЯ ЯКІСТЮ ПРОФЕСІЙНОЇ ПІДГОТОВКИ БАКАЛАВРІВ У ЗАКЛАДАХ ВИЩОЇ ОСВІТИ}

Халіда Бахтіярова,

кандидад педагогічних наук, доцент, Національний транспортний університет ORCID:0000-0001-8274-9581.

e-mail:bakhty@ukr.net

\section{КЛЮЧОВІ СЛОВА:}

якість освіти, принцип системності, управління якістю, показники якості, узагальнюючі оцінки, освітні послуги
Реферат

Послуга професійної вищої освіти є товаром особливого роду і зберігає риси суспільного блага. Тому потреба в послугах освіти виражається через механізм суспільного вибору як прийняття рішення щодо вступу до того чи іншого закладу вищої освіти, на той чи інший факультет, взагалі, обрання відповідного престижного рівня освіти. Така потреба залежить від статусу освіти та висококваліфікованої праці в суспільстві. Вона може стримуватися правилами прийому до закладу освіти, рівнем вимог до якості знань вступників, а також деформуватися відповідною політикою державної підтримки студентства. Більшість освітніх організацій серйозно ставляться до своїх обов'язків. Вони постійно ведуть пошук i підготовку компетентних викладачів, забезпечують необхідне планування освітнього процесу та проведення навчання, при цьому використовують найкращі методичні та навчальні матеріали. Проте закладам освіти часто бракує досвіду застосування системнопроцесного підходу, внаслідок чого вони не виправдовують очікувань студентів, працедавців та суспільства щодо отримання сучасної освіти. Такий парадокс стає можливим тому, що поліпшення індивідуальних елементів не гарантує отримання так званого синергетичного ефекту за відсутності моделі навчання, що базується на управлінні ключовими процесами діяльності закладу освіти. Саме тому впровадження системи управління якістю (далі: СУЯ) дасть змогу створити необхідний ефект для всіх важливих складових їхньої діяльності. 3 огляду на це, у статті проаналізовано проблему якості освіти й освітніх послуг у системі управління, що грунтується на «системно-процесному» підході, коли враховуються вимоги замовників та інших зацікавлених сторін. Саме визначення взаємодіючих процесів і механізмів безперервного покращення результатів стає одним з інструментів розвитку закладу вищої освіти, що, безумовно, підвищує рівень якості випускників, їхню конкурентоспроможність та мобільність на ринку праці.
Постановка проблеми. Вища освіта як суспільно значима діяльність має свої критерії соціальної якості та конкурентноспроможності. Для суб'єкта діяльності він визначається іiі мети та змісту, для об'єкта - єдністю мети та значення в процесі професійної мобільності i працевлаштування. Вплив системних закономірностей на підвищення якості надання освітніх послуг віддзеркалено в документах Болонського процесу, а також у вітчизняних 